\title{
Effect of Sodium Sulphate on the Index Properties and Compaction Behaviour of Neyveli Fly Ash- Shedi Soil Mixtures
}

\author{
Dr.H.N.Ramesh ${ }^{1}$, Dr.H.S.Nanda ${ }^{2}$ and Dr. K.V. Manoj Krishna ${ }^{3}$ \\ ${ }^{I}$ (Department of Civil Engineering, UVCE, / Bangalore University,JB Campus, Bangalore-56,India) \\ ${ }^{2}$ (Principal, Bangalore Technological Institute, / VT University, Bangalore-35,India) \\ ${ }_{3}^{3}$ (Department of Civil Engineering, Govt SKSJTI,/ VT University, K R Circle Bangalor-01, India)
}

\begin{abstract}
This paper presents the effect of abundantly available fly ash, on the index properties namely liquid and plastic limit and compaction characteristics of shedi soil. Shedi soil is a problematic soil that lies between top low level laterite and bottom high level laterites in the western coastal area of Karnataka, India. The effect of sodium salts on this shedi soil optimized with Neyveli Fly ash has also been studied. Considerable changes in the index properties and compaction characteristics were observed which are explained based on series of experimental results. Addition of Neyveli fly ash improved the workability of shedi soil considerably. The addition of sodium sulphate to the optimum combination of shedi soil-Neyveli fly ash mixture increases the shear strength of the mixture. The maximum dry density also found increased with the addition of sodium sulphate.
\end{abstract}

Keywords - Compaction, Laterite, Maximum Dry Density, Neyveli Fly ash

\section{INTRODUCTION}

Current energy policies worldwide consider thermal power generation as a major source of power for industrial development. Fly ash generated from the combustion of coal presently comprises of about million tones every year. Fly ash can be deposited in lagoons or in open dumps. The environmental impact of such disposal schemes in terms of land use, pollution of air and water is quite serious in addition to the enormous cost involved. Research work and studies have been carried out for utilizing fly ash for various purposes to achieve economy and disposal problem. Vast quantities of fly ash have been used in geotechnical engineering for construction of embankments, dams, as backfill behind retaining walls and for land reclamation fill (Faber et al., 1974 [1] ; Holm et al., 1983[2]; Torrey, 1978[3] and Li and Dutton, 1991[4]). The major advantages of using fly ash, as a fill material is its lower specific gravity and higher shear strength. Because of its pozzolanic property, the presence of free lime content and the coarser and inertness of its particles, it can be used for the stabilization of weak soils. Generally the plasticity, workability and strength properties of fine-grained soils are improved by the addition of small quantities of lime (Bell 1988a and 1988b[5]; Dal hunter 1988[6]). Lime-fly ash mixtures have proved to be very effective and economical for use in base and sub-base layers of pavement systems (Torrey, 1978[3]). Dispersive soils, which are highly susceptible to erosion on mixing with fly ash and curing for a sufficient period of time not only become resistant to erosion but also gain strength (Indraratna et al; 1991[7]). The mixtures of lime and fly ash are useful for stabilization of various Indian soils of classes CL, ML, SC and CH, Uppal and Dhawan (1968)[8].Lime-fly ash mixture improved the consistency, shrinkage and unconfined compressive strength of a wide variety of soils, Goecker et al. (1956) [9]. So far, no data are available on the effect of the fly ash content on the index properties and compaction characteristics of shedi soil. To enhance the strength further, sodium salts are often used with fly ash. (Ramesh et al. 1999) [10].

In the coastal area of Karnataka, India, a special type of problematic soil called as shedi soil is available from a depth of about 2 meters to 20 meters, which is underlying relatively good lateritic soil layer. This soil is having size distributive between JEDI (clay) and GODI (silt) soils but do not show the behaivour of the clay nor silt. These soils dissolve and flow like water when ever they come in contact with water which creates cavities and this leads to sliding of the top layers. Hence in this study an attempt is made to study the effect of Neyveli fly ash and sodium sulphate on index properties and compaction characteristics of shedi soil.

\subsection{Material used}

\section{EXPERIMENTAL WORK}

Shedi soil: Shedi soil was collected from shedi gudda near Mangalore, Karnataka State, India by open excavation from a depth of $2 \mathrm{~m}$ below natural ground level. The shedi soil was air-dried and pulverized in a ball mill after separating the pebbles. This pulverized soil which was passed through 425 -micron sieve is used for the investigation. The physical properties of the collected soil sample are presented in Table 1. 
Table 1 Physical Properties of Shedi Soil

\begin{tabular}{|c|c|}
\hline Parameter & Value \\
\hline Colour & Light pink \\
\hline Specific gravity & 2.43 \\
\hline $\begin{array}{ll}\text { Grain size distribution: } \\
\text { Gravel size fraction } & (\%) \\
\text { Sand size fraction } & (\%) \\
\text { Silt size fraction } & (\%) \\
\text { Clay size fraction } & (\%)\end{array}$ & $\begin{array}{c}0.00 \\
0.00 \\
85.00 \\
15.00\end{array}$ \\
\hline $\begin{array}{ll}\text { Atterberg's limits: } & \\
\text { Liquid limit } & (\%) \\
\text { Plastic limit } & (\%) \\
\text { Plasticity index } & (\%)\end{array}$ & $\begin{array}{l}27.00 \\
17.04 \\
9.96\end{array}$ \\
\hline $\begin{array}{l}\text { Compaction characteristics: } \\
\text { Optimum moisture content }(\%) \\
\text { Maximum dry density }\left(\mathrm{kN} / \mathrm{m}^{3}\right)\end{array}$ & $\begin{array}{l}13.70 \\
19.02\end{array}$ \\
\hline Coefficient of permeability $(\mathrm{mm} / \mathrm{sec})$ & $3.652 \times 10^{-6}$ \\
\hline $\begin{array}{l}\text { Consolidation characteristics: } \\
\text { Coefficient of consolidation }(\mathrm{Cv} \mathrm{mm} / \mathrm{sec}) \\
\text { Compression index }\left(\mathrm{Cc} \mathrm{mm}^{2} / \mathrm{sec}\right)\end{array}$ & $\begin{array}{l}70.8 \times 10^{-3} \\
1.69 \times 10^{-3}\end{array}$ \\
\hline $\begin{array}{l}\text { Shear strength parameters: } \\
\text { Friction angle (Degree) } \\
\text { Cohesion }\left(\mathrm{kN} / \mathrm{m}^{2}\right)\end{array}$ & $\begin{array}{c}40^{\circ} \\
13.1\end{array}$ \\
\hline Unconfined compressive strength $\left(\mathrm{kN} / \mathrm{m}^{2}\right)$ & 145.5 \\
\hline
\end{tabular}

Neyveli fly ash: The fly ash was collected from Neyveli lignite corporation, Tamilnadu, India. It is pozzolanic fly ash belonging to the ASTM classification "A" Its physical properties are presented in Table 2.

\section{Table 2 Physical Properties of Neyveli Fly Ash}

\begin{tabular}{|l|c|}
\hline Colour & Dark grey \\
\hline Specific gravity & 2.67 \\
\hline Grain size distribution : & Nil \\
Sand fraction (\%) & 87.00 \\
Silt size fraction (\%) & 31.00 \\
Clay size fraction (\%) & 39.30 \\
\hline Atterberg's limits: & $\mathrm{NP}$ \\
Liquid Limit (\%) & \\
Plastic Limit (\%) & 24.30 \\
\hline Compaction Characters : & 15.20 \\
Optimum Moisture Content (\%) & 124.00 \\
Maximum Dry Density (kN/M $\left.{ }^{3}\right)$ & \\
\hline Unconfined Compressive Strength at MDD & \\
(kN/M ${ }^{2}$ ) & \\
\hline
\end{tabular}

\subsection{Test Procedure}

Soil was mixed with fly ash and all the tests were conducted as per BIS: 2720 guidelines, except for compaction test. Compaction test was conducted using both mini compaction test apparatus (Sridharan and Sivapullaiah,2005) [11] and Light compaction test as per BIS; 2720 Part VII (1980) [12].

\section{Results And Discussions}

The index properties test like atterburg's limits and compaction test were carried out for Shedi soil mixed with various percentage of Neyveli fly ash, shedi soil and optimum percentage of neyveli fly ash mixture treated with $1 \%$ sodium sulphate and the results are discussed. However, the Neyveli fly ash is found to be non-plastic material. 


\subsection{Effect of Neyveli Fly Ash on Liquid Limit of Shedi soil}

Addition of $10 \%$ Neyveli fly ash to shedi soil increases the liquid limit from $27 \%$ to $31.4 \%$ and remains almost constant up to 15 days of curing and then reduces to $24.2 \%$ after 30 days of curing. With further addition of Neyveli fly ash up to $90 \%$, the liquid limit further increases with immediate testing as well as with curing up to 15 days and then reduces marginally after 30days of curing. The variation of liquid limit of shedi soil with the addition of Neyveli fly ash at various curing periods is shown in Fig.1 (a) and Fig.1 (b). On addition of Neyveli fly ash, the liquid limit varies due to (i) the effect of free lime content in the Neyveli fly ash and (ii) the effect of coarser Neyveli fly ash, which acts as diluents, decreases the liquid limit. The increase in liquid limit of shedi soil shows that the effect of flocculation overrides the effect due to reduction in the diffuse double layer thickness and the effect due to dilution. With curing the reduction in liquid limit of shedi soil shows that the effect of dilution dominates the effect due to flocculation.

\subsection{Effect of Sodium Sulphate on the Liquid limit of Neyveli Fly Ash-Shedi Soil mixtures}

With the addition of $1 \%$ Sodium Sulphate to Shedi soil, optimum Neyveli fly ash mixtures the liquid limit decreases on immediate testing. However, there is increase in liquid limit with curing up to 7days and remains almost constant with further curing. The variation of liquid limit of shedi soil optimum Neyveli fly ash mixtures treated with $1 \% \mathrm{Na}_{2} \mathrm{SO}_{4}$ are shown in Table 3 and Fig.2.

Table3 Liquid Limit of Shedi Soil -Optimum Neyveli Fly Ash(NFA) Mixture Treated with 1\% Sodium Sulphate

\begin{tabular}{|c|c|c|c|}
\hline \multirow{2}{*}{ Mixture } & \multicolumn{3}{|c|}{ Liquid Limit (\%) } \\
\cline { 2 - 4 } & \multicolumn{3}{|c|}{ Curing Period } \\
\cline { 2 - 4 } & $\mathbf{0}$ day & $\mathbf{7}$ days & $\mathbf{3 0}$ days \\
\hline Shedi soil (SS) alone & 27 & 27 & 27 \\
\hline $\mathrm{SS}+20 \% \mathrm{NFA}$ & 32.8 & 37.1 & 36.2 \\
\hline $\mathrm{SS}+20 \% \mathrm{NFA}+1 \% \mathrm{Na}_{2} \mathrm{SO}_{4}$ & 27.7 & 36.9 & 36.2 \\
\hline Neyveli fly ash (NFA) alone & 41.2 & 65.8 & 63.2 \\
\hline
\end{tabular}

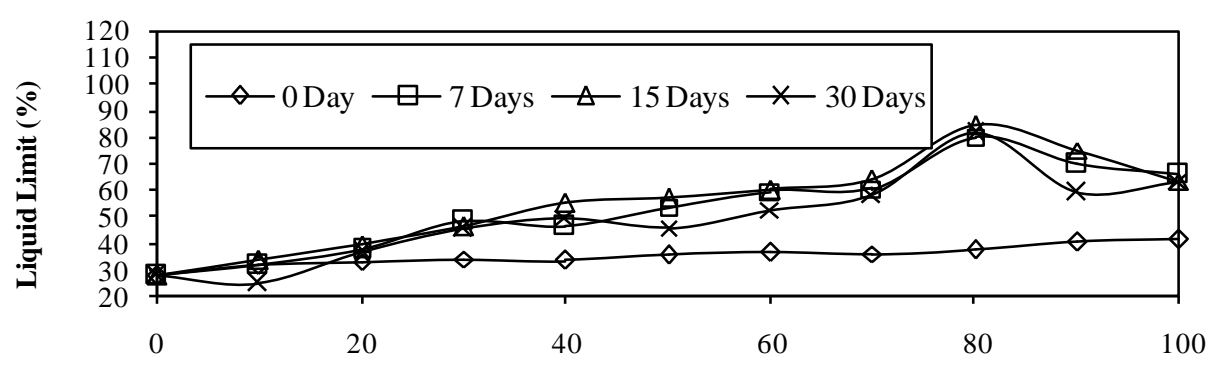

Percentage of NFA

Fig.1(a) Effect of Neyveli Fly Ash (NFA) on the liquid limit of Sheid soil 


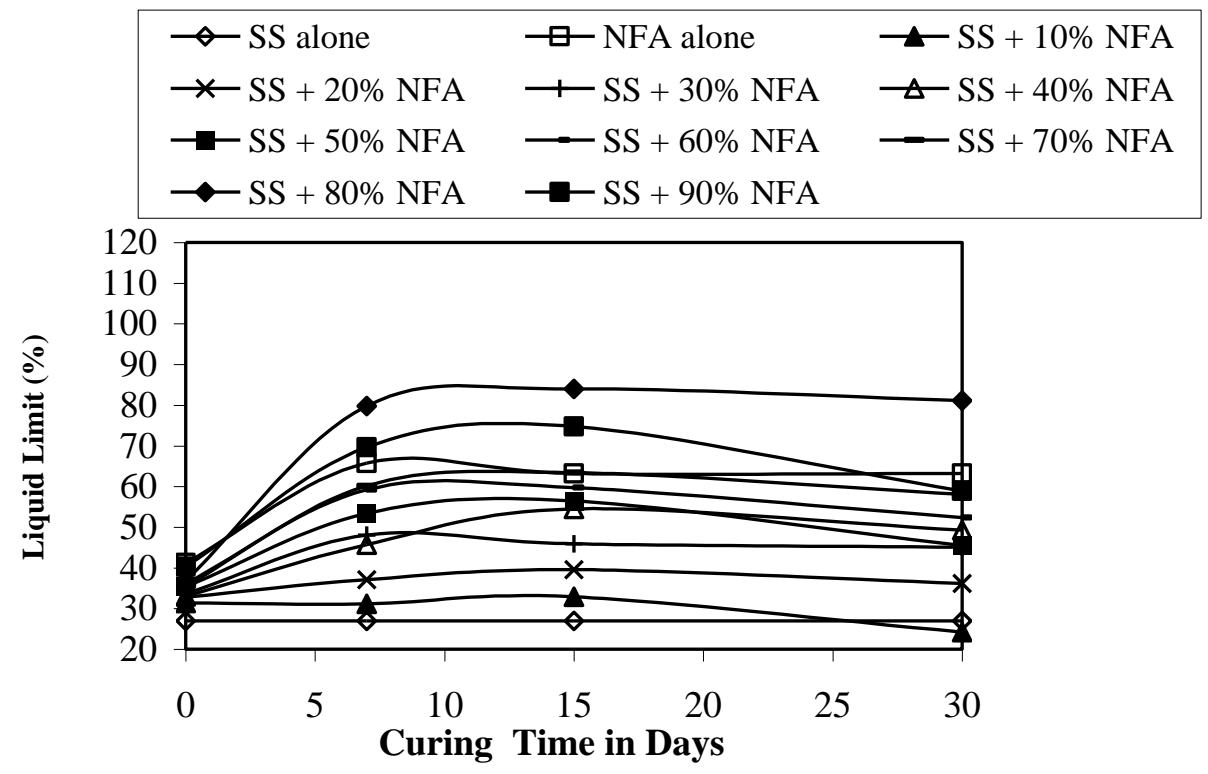

Fig.1(b) Variation of Liquid Limit of Shedi Soil Treated with Various Percentage of NFA

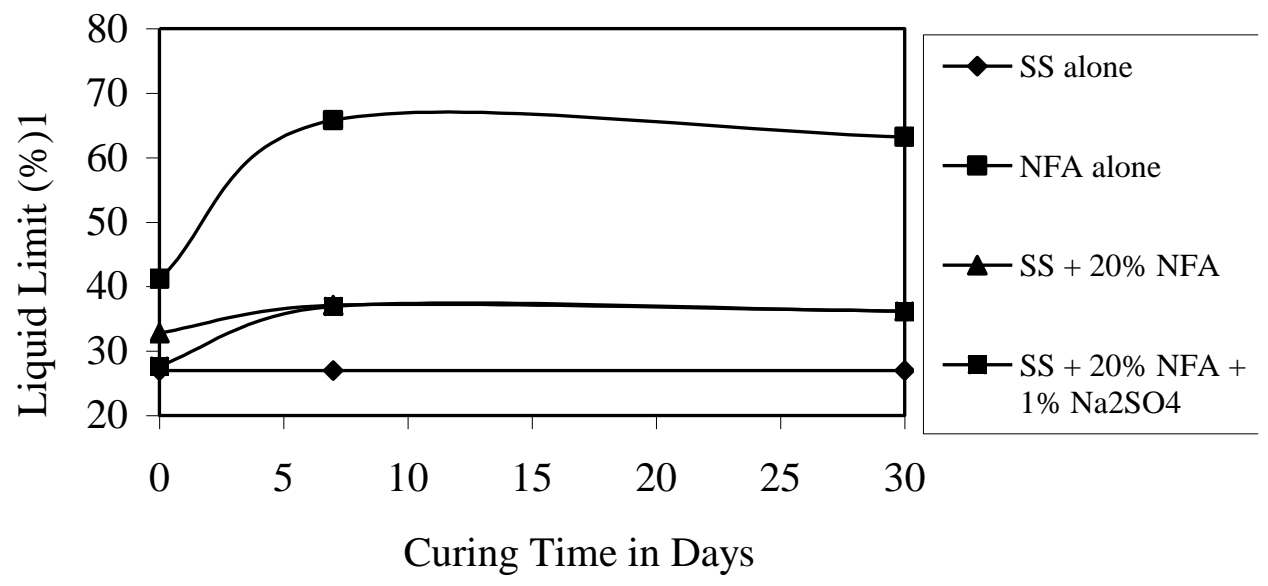

Fig.2 Variation of Liquid Limit of Shedi Soil-NFA mixtures treated with 1\% Sodium Sulphate

\subsection{Effect of Neyveli Fly Ash on Shrinkage Limit of Shedi Soil}

Addition of Neyveli fly ash to shedi soil increases the shrinkage limit both with immediate mixing as well as with various curing period. The shrinkage limit increases with the increase in percentage of Neyveli fly ash. The variation is also shown in Fig. 3. The increase in shrinkage limit with the addition of Neyveli fly ash is mainly due to flocculation of clay particles by free lime present in the Neyveli fly ash and partly due to substitution of finer particles of shedi soil by coarser fly ash particles. Increase in shrinkage limit by addition of coarser fraction is relatively less where as flocculation of lime brings about substantial increase in shrinkage limit. 


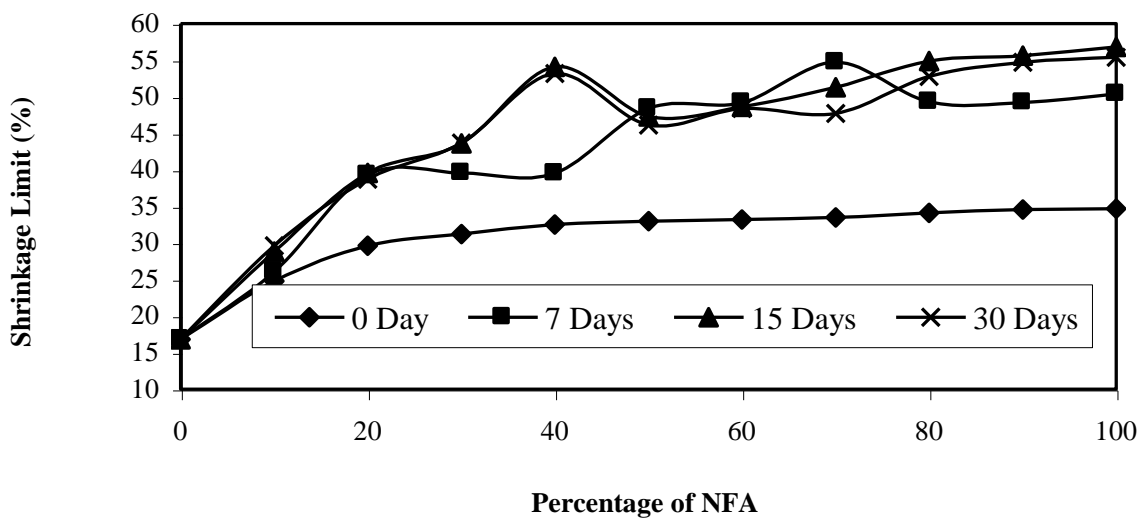

Fig.3 Effect of NFA on Shrinkage Limit of Shedi Soil at Various Curing Periods

\subsection{Effect of Sodium Sulphate on the Shrinkage Limit Behaviour of Neyveli Fly Ash-Shedi Soil Mixtures}

The optimum percentage of Neyveli fly ash for shedi soil is $20 \%$. The optimum percentage of Neyveli fly ash mixed with shedi soil and $1 \% \mathrm{Na}_{2} \mathrm{SO}_{4}$ and the variation of shrinkage limit is studied up to 30days of curing period. The shrinkage limit of shedi soil + optimum Neyveli fly ash is $29.6 \%$ and increases initially to $34.3 \%$ with the addition of $1 \% \mathrm{Na}_{2} \mathrm{SO}_{4}$. However the shrinkage limit decreases with curing period as shown in Table 4 and Fig. 4. While the presence of sulphate may not have any effect on capillary forces, may reduce the shear strength particularly at shrinkage limit water content. Thus it can be seen that, while the liquid limit of lime treated shedi soil has increased in the presence of sulphate, their shrinkage limit is reduced. This confirms that presence of sulphate does not enhance the strength of the soil.

Table 4 Shrinkage Limit of Shedi Soil-Optimum Neyveli Fly Ash Mixture Treated with 1\% Sodium Sulphate

\begin{tabular}{|l|l|l|l|}
\hline \multirow{2}{*}{ A. Mixture } & \multicolumn{3}{|l|}{ Shrinkage Limit (\%) } \\
\cline { 2 - 4 } & \multicolumn{2}{|l|}{ Curing Period } \\
\cline { 2 - 4 } & 0 day & $\mathbf{7}$ days & $\mathbf{3 0}$ days \\
\hline Shedi soil (SS) alone & 16.8 & 16.8 & 16.8 \\
\hline Neyveli fly ash (NFA) alone & 34.7 & 50.4 & 55.4 \\
\hline $\mathrm{SS}+20 \%$ NFA & 29.6 & 39.3 & 38.7 \\
\hline $\mathrm{SS}+20 \% \mathrm{NFA}+1 \% \mathrm{Na}_{2} \mathrm{SO}_{4}$ & 34.3 & 31.2 & 30.7 \\
\hline
\end{tabular}

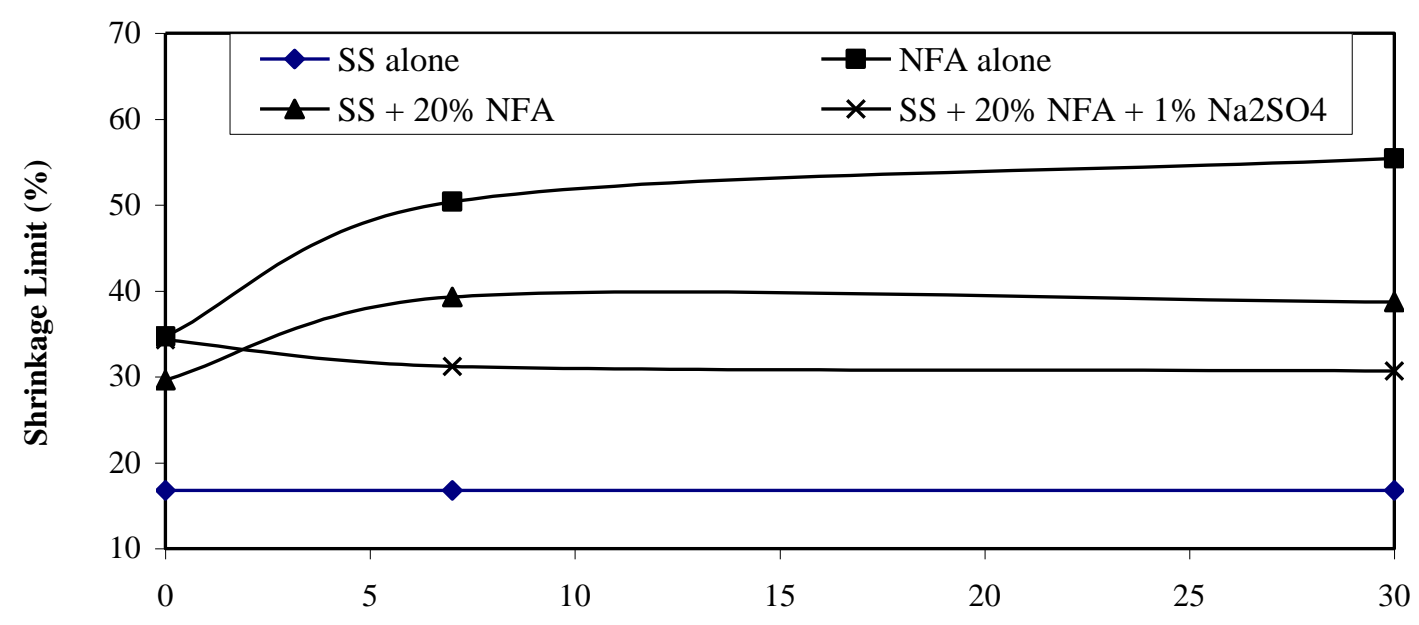

Curing Time in Days

Fig. 4 Variation of Shrinkage Limit of Shedi Soill - NFA Mixture Treated with 1\% Sodium Sulphate 


\subsection{Effect of Neyveli Fly Ash on Compaction Characteristics of Shedi Soil}

As seen from the Table 5 the maximum dry density of shedi soil alone is $19 \mathrm{kN} / \mathrm{m}^{3}$ and the optimum moisture content is $13.6 \%$. Addition of $10 \%$ Neyveli fly ash reduces the maximum dry density and optimum moisture content. Further addition of Neyveli fly ash beyond $20 \%$ the maximum dry density still reduces and optimum moisture content increases. This is due to the fact that percentage of fine fly ash requires more water for interparticle lubrication and at the same time reduces the unit weight (Choudhary, 1994) [13]. The compaction curves for different percentages of Neyveli fly ash are shown in Fig. 5.

Table 5 Compaction Characteristics of Shedi Soil - Neyveli Fly Ash Mixture

\begin{tabular}{|c|c|c|}
\hline Mixture & $\begin{array}{l}\text { Maximum Dry } \\
\text { Density }\left(k N / m^{3}\right)\end{array}$ & $\begin{array}{l}\text { Optimum } \\
\text { Moisture } \\
\text { Content (\%) }\end{array}$ \\
\hline Shedi soil(SS) alone & 19.00 & 13.60 \\
\hline $\mathrm{SS}+10 \% \mathrm{NFA}$ & 18.50 & 13.30 \\
\hline $\mathrm{SS}+20 \% \mathrm{NFA}$ & 18.30 & 11.70 \\
\hline $\mathrm{SS}+30 \% \mathrm{NFA}$ & 17.70 & 15.20 \\
\hline $\mathrm{SS}+40 \% \mathrm{NFA}$ & 17.30 & 15.90 \\
\hline $\mathrm{SS}+50 \% \mathrm{NFA}$ & 16.80 & 18.80 \\
\hline $\mathrm{SS}+60 \% \mathrm{NFA}$ & 16.50 & 17.70 \\
\hline $\mathrm{SS}+70 \% \mathrm{NFA}$ & 16.20 & 21.60 \\
\hline $\mathrm{SS}+80 \% \mathrm{NFA}$ & 16.00 & 23.60 \\
\hline $\mathrm{SS}+90 \% \mathrm{NFA}$ & 15.30 & 23.70 \\
\hline Neyveli fly ash (NFA) alone & 15.24 & 24.00 \\
\hline
\end{tabular}

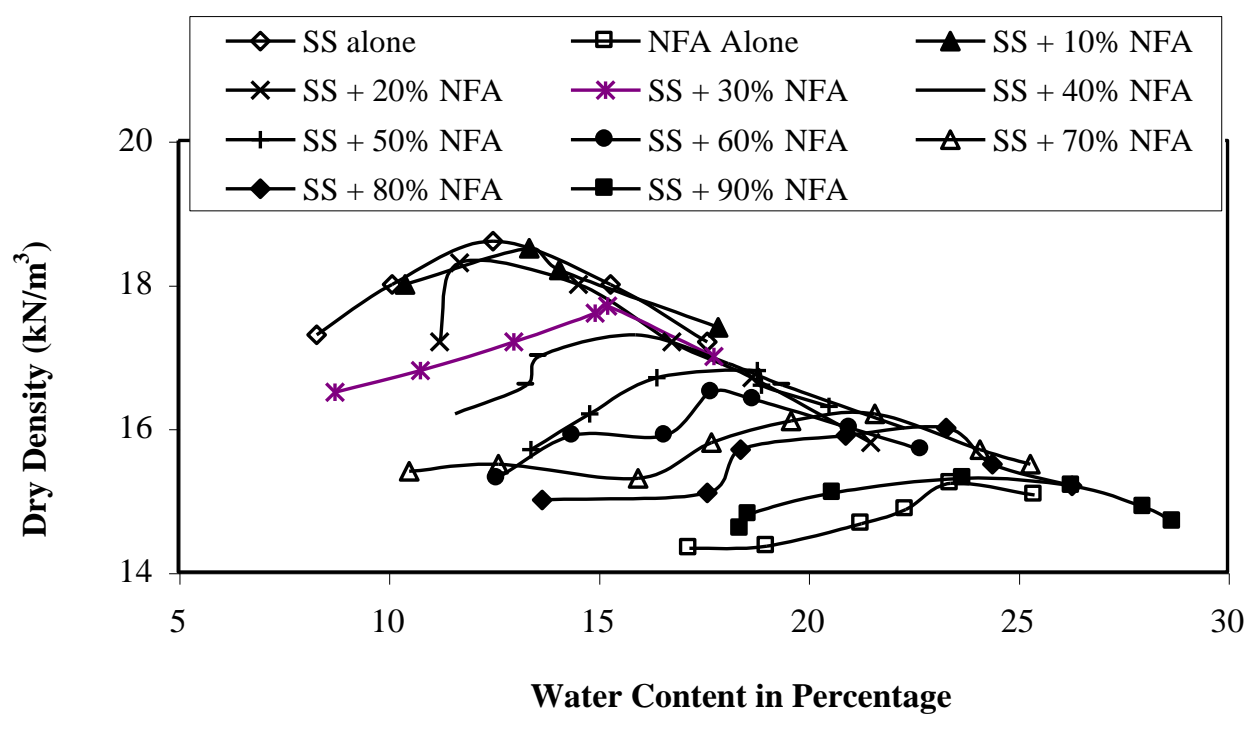

Fig. 5 Density-Water Content Relationship of Shedi Soil Treated with Various Percentage of Neyveli Fly Ash

\subsection{Effect of 1\% Sodium Sulphate on Shedi soil-Neyveli Fly Ash mixtures}

Addition of 20\% Neyveli fly ash has been chosen as optimum percentage to shedi soil. Table 6 shows the variation of maximum dry density and optimum moisture content for shedi soil alone, Neyveli fly ash alone, shedi soil $+20 \%$ Neyveli fly ash and shedi soil $+20 \%$ Neyveli fly ash $+1 \% \mathrm{Na}_{2} \mathrm{SO}_{4}$. Maximum dry density and optimum moisture content increases with the addition of $1 \% \mathrm{Na}_{2} \mathrm{SO}_{4}$ to shedi soil $+20 \%$ Neyveli fly ash mixture. This indicates the improvement in strength of soil for immediate testing with the addition of $1 \%$ $\mathrm{Na}_{2} \mathrm{SO}_{4}$. Fig. 6 clearly indicates the variation of the maximum dry density and optimum moisture content of shedi soil - optimum Neyveli fly ash mixture treated with of $1 \% \mathrm{Na}_{2} \mathrm{SO}_{4}$. 
Effect of Sodium Sulphate on the Index Properties and Compaction Behaviour of Neyveli Fly Ash-

Table 6 Compaction Characteristics of Shedi Soil+Optimum Neyveli Fly Ash Treated with $1 \%$ Sodium Sulphate

\begin{tabular}{|c|c|c|}
\hline Mixture & $\begin{array}{ll}\text { Maximum } & \text { Dry } \\
\text { Density } & \\
\left(\mathbf{k N} / \mathbf{m}^{3}\right) & \\
\end{array}$ & $\begin{array}{l}\text { Optimum } \\
\text { Moisture } \\
\text { Content (\%) }\end{array}$ \\
\hline Shedi soil (SS) alone & 19.00 & 13.60 \\
\hline Neyveli fly ash (NFA) alone & 15.24 & 24.00 \\
\hline $\mathrm{SS}+20 \% \mathrm{NFA}$ & 18.30 & 11.70 \\
\hline $\mathrm{SS}+20 \% \mathrm{NFA}+1 \% \mathrm{Na}_{2} \mathrm{SO}_{4}$ & 18.60 & 13.90 \\
\hline
\end{tabular}

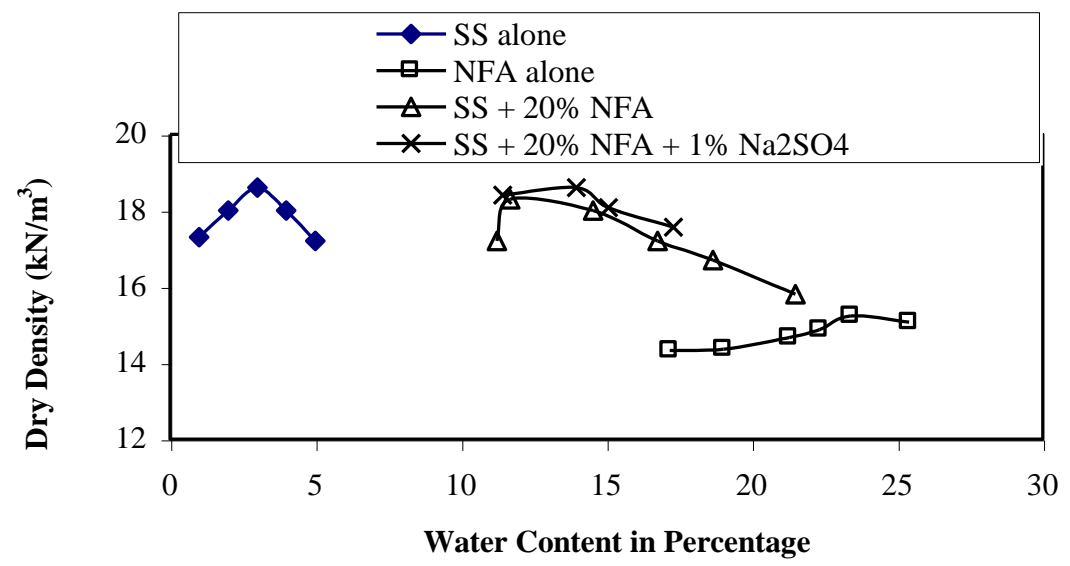

Fig. 6 Density-Water Content Relationship of Shedi Soil+Optimum NFA+1\% Sodium Sulphate

\section{Conclusions}

Based on the detailed experimental investigation and analysis of the results obtained the following conclusions have been drawn:

1.Addition of shedi soil with varying percentage of Neyveli fly ash, liquid limit increases up to 15 days of curing beyond which it reduces.

2.Addition of $1 \%$ sodium sulphate to shedi soil-Neyveli fly ash mixture, liquid limit reduces.

There is an increase in optimum moisture content and decrease in maximum dry density with the increasing percentage of Neyveli fly ash to shedi soil.

3. Maximum dry density and optimum moisture content increases with the addition of $1 \%$ sodium sulphate to shedi soil-Neyveli fly ash mixtures.

\section{REFERENCES}

[1]. J.H.Faber, and A.M.Digioia,(1974). Use of ash in embankment construction, Research Record No.593, Transport Research Board, Washington, D.C., U.S.A., pp. 13 - 19.

[2]. G.Holm, R.Trank, and A.Ekstrom (1983). Improving lime column strength with gypsum. Proc. of VIII European Conference. on SM \& FE, Finnish Geotechnical Soc. pp. 903 - 907.

[3]. S.Torrey, (1978). Coal ash utlization - fly ash, bottom ash and slag, Noyes Data Corp.Park Ridge. NJ.

[4]. K.S. Li, and C.Dutton,(1991). Geotechnical properties of pulverized fuel ash as a reclamation fill, 9th ARC, Theme 5.

[5]. F.G. Bell (1988a). Stabilization and treatment of clay soils with lime part I - Basic principles, Ground Engineering, Vol. 21 , pp. 10 15 .

[6]. Dal Hunter, (1988). Lime induced heave in sulphate bearing clay soil, Journal of Geotechnical Engineering Division, ASCE, Vol.114, No.2, pp.150 - 167.

[7]. B. Indraratna, P.Nutalaya. and N. Kuganenthira(1991). Stabilization of dispersive soil by blending with fly ash, Journal of Engineering Geology, No.24, pp. 275 - 290.

[8]. H.L.Uppal, and P.K. Dhawan, (1968). A resume on the use of fly ash in soil stabilization, Road Research Papers, No.95.

[9]. W.L. Goecker (1956) . Stabilization of fine coarse grained soils with lime and fly ash mixtures, H .R. B. Bulletin 129 , pp.63

[10]. H.N. Ramesh, Sivamohan and P..V. Sivapullaiah (1999). Improvement of strength of fly ash with lime and sodium salts, Ground Improvement, No.3, pp.163 - 167.

[11]. A.Sridharan, and P.V.Sivapullaiah (2005). Mini compaction test apparatus for fine grained soils, ASTM Journal of Testing and Evaluation, Vol.28, No.3, pp. $240-246$.

[12]. BIS 2720 (Part VII) (1980), Determination of Light compaction, Bureau of Indian Standards, New Delhi.

[13]. A.K. Choudhary, (1994). Influence of fly ash on the characteristics of expansive soil, Indian Geotechnical Journal, pp. 215 - 218. 